\title{
Ecological trends in the wood anatomy of Vaccinioideae (Ericaceae s.l.)
}

\author{
Frederic Lens ${ }^{1}$, JAmes L. Luteyn ${ }^{2}$, ERiK SMets $^{1} \&$ Steven JANSEN ${ }^{1}$ \\ 1 Laboratory of Plant Systematics, Institute of Botany and Microbiology, K.U.Leuven, Kasteelpark Arenberg 31, \\ B-3001 Leuven, Belgium. \\ 2 The New York Botanical Garden, Bronx, NY 10458-5126
}

Submitted: Oct 23, 2003 • Accepted: Feb 11, 2004

\section{Summary}

The ecological wood anatomy of 128 vaccinioid wood samples (including 115 species, 35 genera), collected between $39^{\circ} \mathrm{S}$ and $60^{\circ} \mathrm{N}$ latitude and $10 \mathrm{~m}$ to $3400 \mathrm{~m}$ altitude is studied. Several wood anatomical features within the subfamily, viz. tangential vessel diameter, average length of tracheary elements, height of multiseriate rays, and presence of prismatic crystals are negatively correlated with increasing latitude, while vessel density and helical thickenings show a positive correlation with increasing latitude. Similar latitudinal trends are found within the genus Vaccinium (31 species studied). The correlation between various wood anatomical features and latitude is surprisingly high despite the fact that most tropical species grow in montane regions, which are rather similar to the temperate, non-tropical habitats as regards climatic conditions. Altitudinal trends, however, are weak. The impact of different life forms (shrubs, trees and lianas) and the amount of precipitation also plays a significant role in various continuous wood features. Furthermore, some of these anatomical features are correlated with each other. Part of the variation in vessel characters may be the result of functional adaptations to different climatic zones and environments, especially with respect to conductive efficiency and safety.

Key words: Altitude, Ecological and functional wood anatomy, Ericaceae, Latitude, Vaccinioideae, Vaccinium

\section{Introduction}

Functionally adaptive xylem evolution and the dominant role of macroclimatic adaptation have been documented repeatedly in the literature. A number of studies on the relations of wood anatomy to ecology are reported within species (e.g. Noshiro \& SUZUKI 1995; NoSHIRO \& BAAS 2000; LIU \& NOSHIRO 2003), in genera (e.g. BAAS 1973; VAN DEN OEver et al. 1981; NoshIRO et al. 1995), and within families (e.g. DicKISON \& PHEND 1985; BAAs et al. 1988; ZHANG et al. 1992; Noshiro \& BaAs 1998; KLAASSEN 1999). Similar studies have also been conducted for different regional floras (e.g. BaAs et al. 1983; CARLQUist \& HoEKMAN 1985; BAAS \& SCHWEINGRUBER 1987) and some gene- ral ecological trends suggested were reviewed (BAAS 1982, 1986; DiCKISON 1989; CARLQUist 1975, 2001). Most ecological trends conform to correlations established previously, but the degree of adaptation to ecological gradients may differ considerably among plant groups. For instance, in Rosaceae the percentage of anatomical variation explained by ecological factors was claimed to be relatively low (2-10\%) (ZHANG et al. 1992), while latitudinal and altitudinal trends are manifest within for instance Symplocos (VAN DEN OEvER et al. 1981).

According to the most recent classification of Ericaceae, the subfamily Vaccinioideae consists of five tribes, viz. Andromedeae s.s., Gaultherieae, Lyonieae, Oxydendreae and Vaccinieae, comprising about 48 genera

\footnotetext{
* Corresponding author : Frederic Lens, Laboratory of Plant Systematics, Institute of Botany and Microbiology, K.U.Leuven, Kasteelpark Arenberg 31, B-3001 Leuven, Belgium, e-mail: frederic.lens@bio.kuleuven.ac.be
} 
and more than 1325 species (KRON et al. 2002). Most Vaccinioideae are evergreen shrubs, including many epiphytes, whereas lianas and trees occur sporadically. The vast majority of taxa (about 32 genera and 1000 species, mainly belonging to Vaccinieae) are concentrated in the cool and moist montane areas of South America between $1500 \mathrm{~m}$ and $3000 \mathrm{~m}$, although some species grow above $3000 \mathrm{~m}$ in páramo vegetation and others below $100 \mathrm{~m}$ in tropical lowland rainforest to mangroves (LUTEYN 2002). Most other members of Vaccinioideae grow in temperate to arctic regions of the northern hemisphere, in the montane regions of tropical Asia, and only a few species are restricted to southeast Africa and Madagascar. Vaccinium, the only genus that occurs in temperate regions as well as in the tropics of the Old and New World, is by far the largest genus of the subfamily including about 450 species. In addition to two recent studies of the systematic wood anatomy of Vaccinioideae (LENS et al. 2004, submitted), the wide ecological distribution of the study group raises interesting questions about the ecological impact on variation of secondary xylem.

Our previous wood anatomical studies on Vaccinioideae illustrate that several wood anatomical features, especially the arrangement and type of vessel-ray pitting, the width and height of multiseriate rays, the shape of the body ray cells in multiseriate rays, and the presence and location of prismatic crystals, largely support recent changes in phylogeny based on morphological and molecular data (KRON et al. 2002). This paper aims to investigate the impact of various ecological influences on secondary xylem within the subfamily. In order to do this, we have investigated 12 wood anatomical features of 128 wood specimens representing 115 species and 35 genera. These anatomical characters are evaluated according to rough ecological factors, both at the subfamily level and within the genus Vaccinium (31 species). Furthermore, correlations are investigated between most of the characters studied. This research also explores the impact of different life forms (shrubs, trees and lianas) on several continuous, wood anatomical features.

\section{Material and methods}

The material used is based on two previous studies on the systematic wood anatomy of the subfamily (LENS et al. 2004, submitted, see appendix). Wood specimens derived from juvenile stems were excluded, because of possible ontogenetic differences between juvenile and mature wood (NoshIRo \& SUZUKI 2001). However, mature wood could not always be easily defined within the study group. For example, a thin wood sample of less than $10 \mathrm{~mm}$ diameter with a relatively large amount of pith tissue was considered to be juvenile, while some wood samples with a diameter of $6 \mathrm{~mm}$ that showed a small amount of pith area together with several growth rings were regarded as mature. Also, we omitted all specimens for which no detailed ecological data were available, including altitude, latitude, the annual amount of precipitation and the presence or absence of frost. In addition, non-standardized sampling may have influenced quantitative data, but it is believed that this represents random sources of variation that cannot have influenced the general results substantially. As a result, 128 mature samples were used to trace major ecological trends in the wood of Vaccinioideae. With the aid of regression analyses, these trends are illustrated using the program Microsoft Excel version X (Macintosh). The sta-

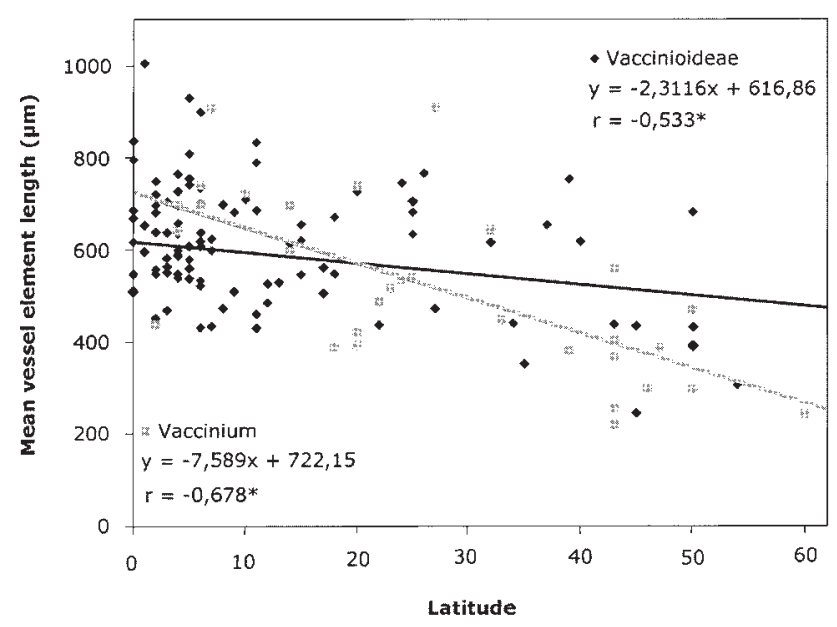

Fig. 1. Scatter plot of mean vessel element length and latitude for Vaccinioideae and Vaccinium with linear curve fitting. An asterisk means that the r-value is significant at the $0.5 \%$ significance level.

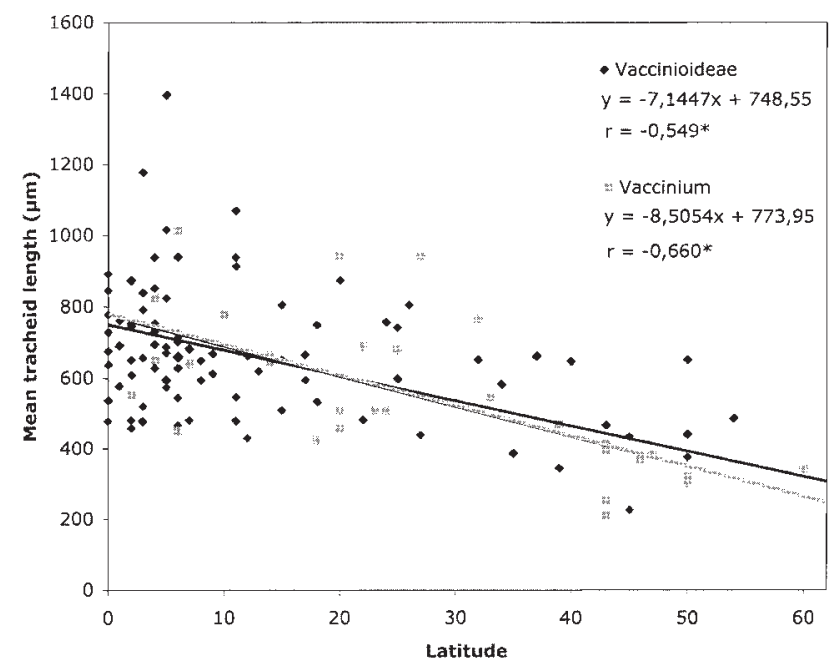

Fig. 2. Scatter plot of mean tracheid length and latitude for Vaccinioideae and Vaccinium with linear curve fitting. An asterisk means that the r-value is significant at the $0.5 \%$ significance level. 


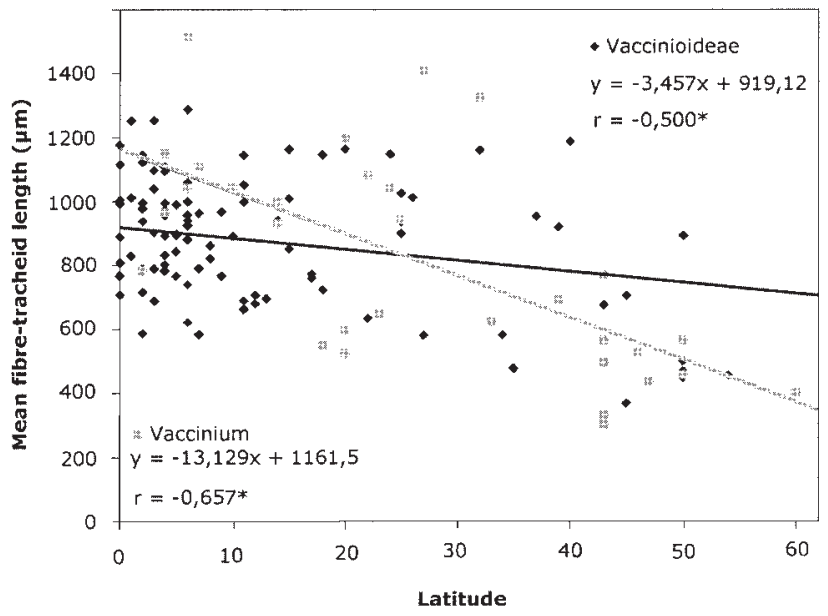

Fig. 3. Scatter plot of mean fibre-tracheid length and latitude for Vaccinioideae and Vaccinium with linear curve fitting. An asterisk means that the r-value is significant at the $0.5 \%$ significance level.

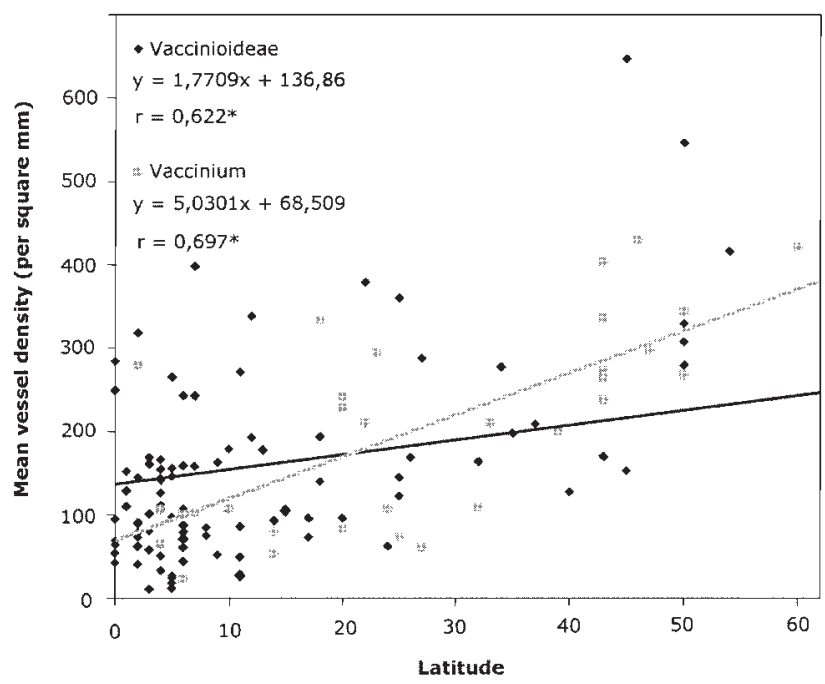

Fig. 5. Scatter plot of mean vessel density and latitude for Vaccinioideae and Vaccinium with linear curve fitting. An asterisk means that the r-value is significant at the $0.5 \%$ significance level.

tistical significance of correlation coefficients and differences between mean values were analysed at the $0.5 \%$ significance level with the software package Statistics Calculator version 8.0.

The qualitative wood anatomical features analysed were as follows: presence of distinct growth rings, the occurrence of helical wall thickenings, and the presence of mineral inclusions. The quantitative characters included the tangential vessel diameter and vessel density, the percentage of scalariform perforation plates, the length of vessel elements, tracheids, fibre-tracheids and libriform fibres, and the height and width of multiseriate rays.

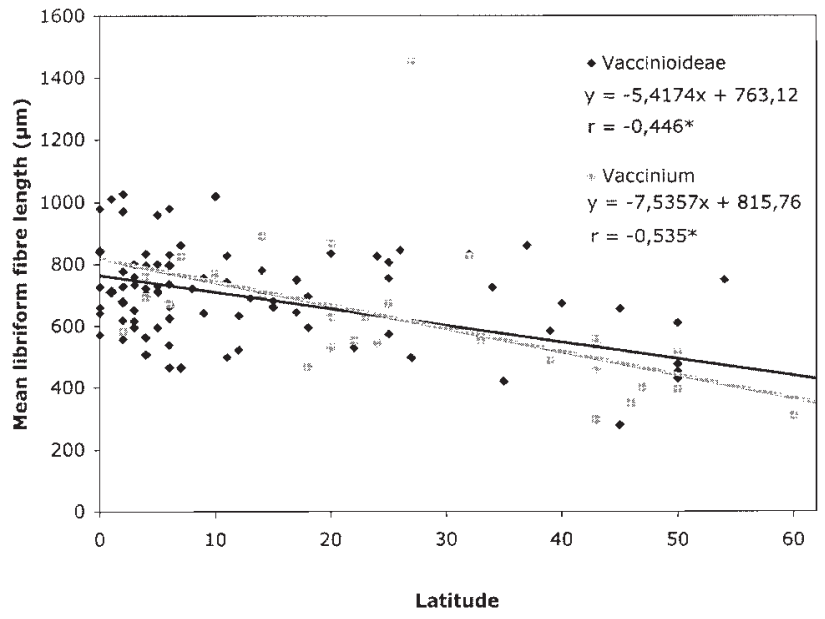

Fig. 4. Scatter plot of mean libriform fibre length and latitude for Vaccinioideae and Vaccinium with linear curve fitting. An asterisk means that the r-value is significant at the $0.5 \%$ significance level.

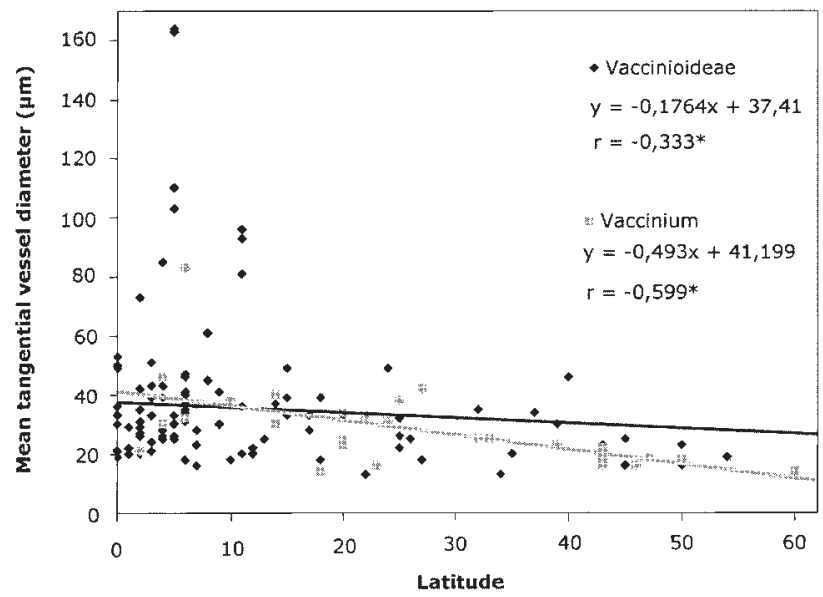

Fig. 6. Scatter plot of mean tangential vessel diameter and latitude for the vaccinioids studied with linear curve fitting. An asterisk means that the r-value is significant at the $0.5 \%$ significance level.

In order to discuss the influence of growth forms on wood anatomical features, we distinguished three groups within the species studied, viz. shrubs, trees and lianas. Shrubs are defined as multi-stemmed plants which are usually smaller than three metres, while trees are single-stemmed plants usually more than three metres high.

Because exact precipitation data for most species could not be found, the origins of the specimens studied were divided into three arbitrary categories, viz. (1) areas with an annual precipitation from $500 \mathrm{~mm}$ to $1000 \mathrm{~mm}$, (2) from $1000 \mathrm{~mm}$ to $2500 \mathrm{~mm}$, and (3) areas with more than $2500 \mathrm{~mm}$ annual precipitation. 


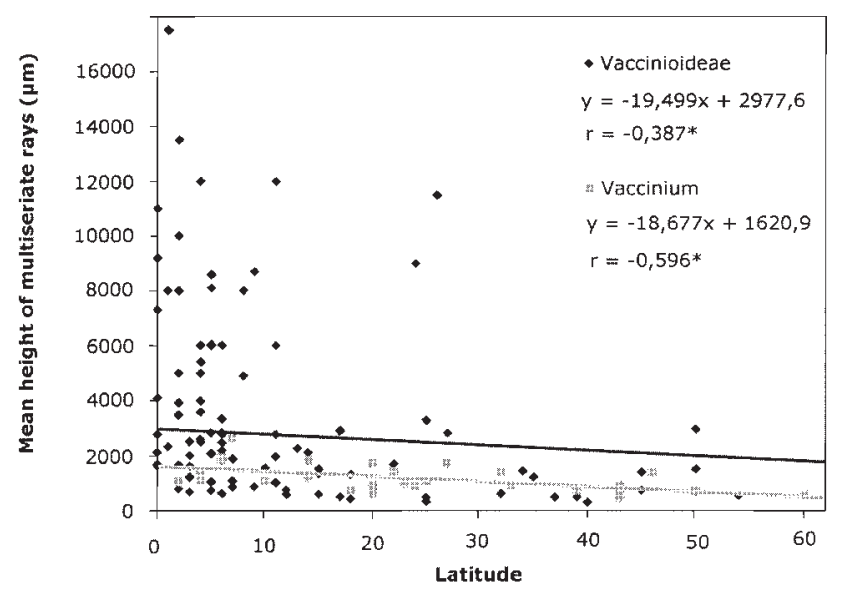

Fig. 7. Scatter plot of mean multiseriate ray height and latitude for Vaccinioideae and Vaccinium with linear curve fitting. An asterisk means that the r-value is significant at the $0.5 \%$ significance level.

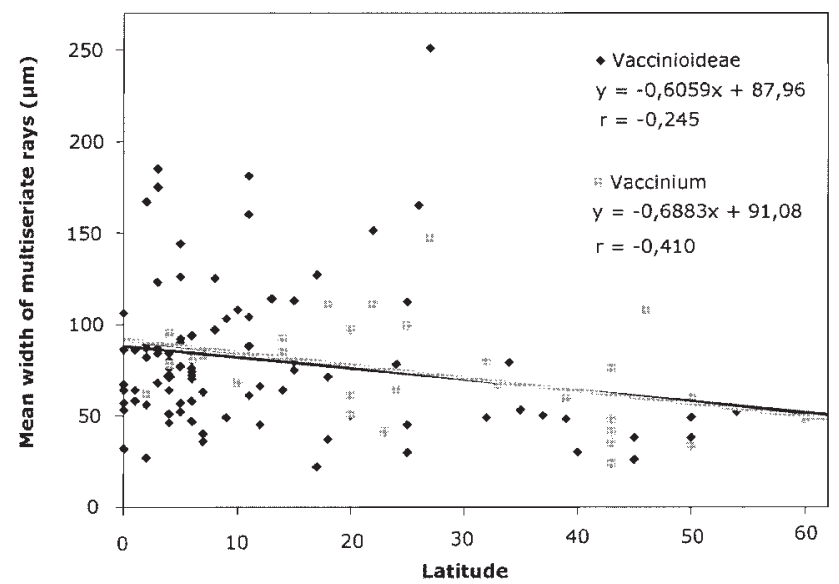

Fig. 8. Scatter plot of mean multiseriate ray width and latitude for Vaccinioideae and Vaccinium with linear curve fitting.

Table 1. Correlations of non-anatomical and wood anatomical characters of Vaccinioideae. LAT: latitude, SPP: percentage of scalariform perforation plates, VDIAM : mean tangential vessel diameter $(\mu \mathrm{m})$, VDEN : mean vessel density $\left(/ \mathrm{mm}^{2}\right)$, VEL: mean vessel element length $(\mu \mathrm{m})$, TL: mean tracheid length $(\mu \mathrm{m})$, FTL: mean fibre-tracheid length $(\mu \mathrm{m})$, LFL: mean libriform fibre length $(\mu \mathrm{m}), \mathrm{MRH}$ : mean multiseriate ray height $(\mu \mathrm{m}), \mathrm{MRW}$ : mean multiseriate ray width $(\mu \mathrm{m})$, ALT: altitude

LAT SPP VDIAM VDEN VEL TL FTL LFL MRH MRW ALT

Latitude $(\mathrm{n}=128)$

$\%$ scalariform perforation plates

Mean vessel diameter

Mean vessel density

Mean vessel element length

Mean tracheid length

Mean fibre-tracheid length

Mean libriform fibre length

Mean multiseriate ray height

Mean multiseriate ray width

Altitude $(\mathrm{n}=108)$

Significance level: $*=0.5 \%$

Table 2. Correlations of non-anatomical and wood anatomical characters of Vaccinium. LAT: latitude, SPP: percentage of scalariform perforation plates, VDIAM: mean tangential vessel diameter $(\mu \mathrm{m})$, VDEN : mean vessel density $\left(/ \mathrm{mm}^{2}\right)$, VEL: mean vessel element length $(\mu \mathrm{m})$, TL: mean tracheid length $(\mu \mathrm{m})$, FTL: mean fibre-tracheid length $(\mu \mathrm{m})$, LFL: mean libriform fibre length $(\mu \mathrm{m})$, MRH: mean multiseriate ray height $(\mu \mathrm{m})$, MRW: mean multiseriate ray width $(\mu \mathrm{m})$, ALT: altitude

\begin{tabular}{|c|c|c|c|c|c|c|c|c|c|c|}
\hline & LAT & SPP & VDIAM & VDEN & VEL & $\mathrm{TL}$ & FTL & LFL & MRH & MRW ALT \\
\hline Latitude $(\mathrm{n}=31)$ & - & & & & & & & & & \\
\hline$\%$ scalariform perforation plates & 0.263 & - & & & & & & & & \\
\hline Mean vessel diameter & $-0.599 *$ & $-0.515^{*}$ & - & & & & & & & \\
\hline Mean vessel density & $0.697 *$ & 0.343 & $-0.779 *$ & - & & & & & & \\
\hline Mean vessel element length & $-0.678 *$ & -0.254 & $0.702 *$ & $-0.855^{*}$ & - & & & & & \\
\hline Mean tracheid length & $-0.660 *$ & -0.411 & $0.798 *$ & $-0.823 *$ & $0.820 *$ & - & & & & \\
\hline Mean fibre-tracheid length & $-0.657^{*}$ & -0.286 & $0.806^{*}$ & $-0.875^{*}$ & $0.894 *$ & $0.914^{*}$ & - & & & \\
\hline Mean libriform fibre length & $-0.536^{*}$ & -0.081 & $0.766^{*}$ & $-0.776 *$ & $0.895 *$ & $0.849 *$ & $0.848 *$ & - & & \\
\hline Mean multiseriate ray height & $-0.596^{*}$ & -0.421 & $0.602 *$ & $-0.631 *$ & $0.797 *$ & $0.652^{*}$ & $0.749 *$ & $0.617 *$ & - & \\
\hline Mean multiseriate ray width & -0.410 & -0.147 & 0.402 & -0.460 & $0.585 *$ & $0.610^{*}$ & $0.631 *$ & $0.622 *$ & $0.604 *$ & - \\
\hline Altitude $(n=22)$ & $-0.623^{*}$ & -0.126 & 0.322 & -0.153 & 0.237 & 0.286 & 0.227 & 0.126 & 0.132 & $0.140-$ \\
\hline
\end{tabular}

$-$

$0.127-$

$0.622 * 0.418 *-0.572 *-$

$-0.533 *-0.2380 .488 *-0.650 *-$

$-0.549 *-0.371 * 0.697 *-0.723 * 0.785 *-$

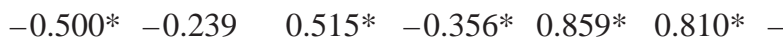

$-0.446 *-0.1790 .412 *-0.301 * 0.804 * 0.742 * 0.779 *-$

$\begin{array}{lllllll}-0.387 *-0.255 & 0.303 * & -0.702 * & 0.466 * & 0.349 * & 0.299 * 0.369 * & \end{array}$

$\begin{array}{lllllllll}-0.245 & -0.381 * & 0.317 * & -0.651 * & 0.236 & 0.355^{*} & 0.214 & 0.238 & 0.299 *\end{array}$

$\begin{array}{llllllllll}-0.630 * & 0.158 & -0.033 & -0.286 * & 0.206 & 0.039 & 0.156 & 0.063 & 0.106 & 0.007\end{array}-$

Significance level: $*=0.5 \%$ 


\section{Results}

Within the subfamily, the average length of vessel elements, tracheids, fibre-tracheids and libriform fibres shows a negative correlation with increasing latitudinal ranges $(\mathrm{r}=-0.533,-0.549,-0.500$ and -0.446 , respectively, Figs. 1-4), while vessel density is positively correlated with latitude $(r=0.622$, Fig. 5$)$. These correlations are all statistically significant at the $0.5 \%$ level (Tab. 1). Vessel diameter illustrates a weaker, but still significant at $0.5 \%$, negative trend $(r=-0.333$, Fig. 6). The frequency of scalariform perforations is not correlated with latitude $(\mathrm{r}=0.127)$. There is also a minor increase of multiseriate ray frequency with increasing latitude $(r=0.073)$, and a slight decrease in multiseriate ray width $(\mathrm{r}=-0.245$, Fig. 8$)$. However, ray height is significantly correlated with latitude $(\mathrm{r}=-0.387$, Fig. 7).

Within the genus Vaccinium, similar significant correlations with latitude are found (Figs. 1-8, Tab. 2). Relatively higher $\mathrm{r}$-values are found for vessel diameter $(r=-0.599)$ and height of multiseriate rays $(\mathrm{r}=-0.596)$ in Vaccinium, as compared to the overall subfamily.

Three qualitative wood features, viz. the presence of distinct growth rings, helical thickenings throughout vessel elements, tracheids or fibres, and the occurrence of prismatic crystals, show interesting latitudinal trends. Distinct growth rings are present in $44 \%$ of (sub)tropical, mostly montane species $(\mathrm{n}=100)$, while this percentage increases to $86 \%$ in the temperate to boreal species $(n=28)$. Helical thickenings occur in tracheary elements from $17 \%$ of (sub)tropical species to $64 \%$ of temperate to boreal species. Prismatic crystals, on the other hand, are present in $47 \%$ of species growing in (sub)tropical regions, but only $14 \%$ of the species from temperate to boreal areas. In the genus Vaccinium, similar trends are found. Tropical Vaccinium species $(\mathrm{n}=17)$ less frequently show distinct growth rings $(41 \%)$ and helical hickenings $(35 \%)$, and a slightly higher incidence of prismatic crystals $(24 \%)$ than temperate to boreal Vaccinium species $(n=14)$, which have percentages of $93 \%, 64 \%$ and $14 \%$, respectively.

There is a clearly positive correlation between vessel diameter and length of the tracheary elements, and a negative correlation with respect to vessel density (Tab. 1). In addition, the length of the different types of tracheary elements is clearly related to each other. The incidence of scalariform perforations is negatively correlated with tangential vessel diameter $(r=-0.543)$, while a positive correlation is found for mean vessel density $(r=0.418)$. Moreover, mean vessel density is negatively correlated with tangential vessel diameter $(r=-0.572)$, and with mean height and width of multi- seriate rays $(\mathrm{r}=-0.702$ and -0.651 , respectively). Similar but usually stronger correlations are found within the genus Vaccinium. However, one may not compare the r-values of Vaccinioideae as a whole with Vaccinium because of difference in sampling between these two groups (128 vs. 31 samples, respectively; Tab. 1-2).

Based on altitudinal data within the subfamily, we only find a single wood anatomical feature that is significantly correlated with increasing altitude at the $0.5 \%$ significance level, i.e. vessel density $(r=0.286$, Tab. 1). There is a slightly positive, but not significant correlation between vessel element length and altitude. A comparison of all species growing in the Andes region between $1500 \mathrm{~m}$ and $3500 \mathrm{~m}$, representing 53\% of the total number of species studied, illustrates that none of the wood features are correlated with altitude at the $0.5 \%$ significance level. Moreover, no significant altitudinal correlations are found in Vaccinium (Tab. 2).

According to the habit of the species studied, a considerable proportion of wood anatomical variation can be explained (Tab.3). For example, the presence of scalariform perforations is more abundant in shrubs (71.9\%) than in trees and lianas (56.9 and 14.5\%, respectively). In addition, mean length of vessel elements, tracheids, fibre-tracheids and libriform fibres is higher in trees compared with shrubs, but only the difference of tracheid and fibre-tracheid length is significant at the $0.5 \%$ level. Except for a similar mean length of fibre-tracheids in trees and lianas, the highest values occur in lianas. Similar differences account for tangential diameter of vessels and mean width of multiseriate rays, while the opposite holds true for mean vessel density. Of these three features, especially differences between shrubs and lianas are statistically significant (Tab. 3). On the other hand, the lowest mean height of multiseriate rays is found in trees, while multiseriate rays are higher in shrubs and especially in lianas.

The correlations found between species from the three precipitation categories correspond with the correlations described above based on habit differences. Species growing in areas with an annual precipitation of 500 to $1000 \mathrm{~mm}$ show the narrowest vessel diameter, shortest tracheary elements, highest percentage of scalariform perforations and highest vessel density, although this tendency is not clear for the percentage of scalariform perforations and vessel diameter (Tab. 4). Species growing in regions with more than 2500 annual precipitation usually show a significant opposite trend, while species in the 1000 to $2500 \mathrm{~mm}$ precipitation zone represent intermediate values (except for fibre-tracheid length, multiseriate ray height and width). 
Table 3. Mean values and standard deviation of selected continuous, wood anatomical features for shrubs $(\mathrm{S}, \mathrm{n}=105)$, trees $(\mathrm{T}, \mathrm{n}=13)$ and lianas $(\mathrm{L}, \mathrm{n}=10)$. The statistical significance $(P)$ between the mean values at the $0.5 \%$ level is indicated for the three categories.

\begin{tabular}{lcccl}
\hline & Shrubs & Trees & Lianas & $P$ \\
\hline \% scalariform perforation plates & $71.9 \pm 34.0$ & $56.9 \pm 43.5$ & $14.5 \pm 31.1$ & $\mathrm{~S}-\mathrm{L}$ \\
Vessel diameter $(\mu \mathrm{m})$ & $28.6 \pm 11.1$ & $39.1 \pm 7.38$ & $102 \pm 36.1$ & $\mathrm{~S}-\mathrm{L}, \mathrm{T}-\mathrm{L}$ \\
Vessel density $\left(/ \mathrm{mm}^{2}\right)$ & $183 \pm 118$ & $102 \pm 49.1$ & $32.7 \pm 16.6$ & $\mathrm{~S}-\mathrm{L}$ \\
Vessel element length $(\mu \mathrm{m})$ & $563 \pm 153$ & $641 \pm 69.7$ & $747 \pm 110$ & $\mathrm{~S}-\mathrm{L}$ \\
Tracheid length $(\mu \mathrm{m})$ & $588 \pm 164$ & $763 \pm 154$ & $954 \pm 187$ & $\mathrm{~S}-\mathrm{T}, \mathrm{S}-\mathrm{L}$ \\
Fibre-tracheid length $(\mu \mathrm{m})$ & $819 \pm 235$ & $1086 \pm 157$ & $1075 \pm 77$ & $\mathrm{~S}-\mathrm{T}, \mathrm{S}-\mathrm{L}$ \\
Libriform fibre length $(\mu \mathrm{m})$ & $647 \pm 176$ & $762 \pm 85.1$ & $855 \pm 117$ & $\mathrm{~S}-\mathrm{L}$ \\
Multiseriate ray height $(\mu \mathrm{m})$ & $2912 \pm 3217$ & $1100 \pm 653$ & $5663 \pm 3422$ & $\mathrm{~T}-\mathrm{L}$ \\
Multiseriate ray width $(\mu \mathrm{m})$ & $74.4 \pm 34.7$ & $81.7 \pm 52.2$ & $110 \pm 39.9$ & $\mathrm{~S}-\mathrm{L}$ \\
\hline
\end{tabular}

Table 4. Mean values and standard deviation of selected continuous, wood anatomical features for species growing in areas with a annual precipitation between $500 \mathrm{~mm}$ and $1000 \mathrm{~mm}$ (region A, $\mathrm{n}=30$ ), from $1000 \mathrm{~mm}$ to $2500 \mathrm{~mm}$ (region $\mathrm{B}, \mathrm{n}=15$ ), and areas with more than $2500 \mathrm{~mm}$ (region $\mathrm{C}, \mathrm{n}=83$ ). The statistical significance $(P)$ between the mean values at the $0.5 \%$ level is indicated for the three categories.

\begin{tabular}{lcccc}
\hline & $500-1000$ & $1000-2500$ & $>2500$ & $P$ \\
\hline \% scalariform perforation plates & $79 \pm 29.1$ & $66 \pm 36.9$ & $61 \pm 40.1$ & $/$ \\
Mean vessel diameter $(\mu \mathrm{m})$ & $26 \pm 14.4$ & $31 \pm 8.4$ & $40 \pm 27.7$ & $/$ \\
Mean vessel density $\left(/ \mathrm{mm}^{2}\right)$ & $260 \pm 148$ & $166 \pm 81.2$ & $128 \pm 88.5$ & $\mathrm{~A}-\mathrm{C}$ \\
Mean vessel element length $(\mu \mathrm{m})$ & $481 \pm 178$ & $568 \pm 132$ & $626 \pm 126$ & $\mathrm{~A}-\mathrm{C}$ \\
Mean tracheid length $(\mu \mathrm{m})$ & $486 \pm 201$ & $633 \pm 171$ & $689 \pm 171$ & $\mathrm{~A}-\mathrm{C}$ \\
Mean fibre-tracheid length $(\mu \mathrm{m})$ & $713 \pm 328$ & $927 \pm 247$ & $906 \pm 174$ & $\mathrm{~A}-\mathrm{B}, \mathrm{A}-\mathrm{C}$ \\
Mean libriform fibre length $(\mu \mathrm{m})$ & $583 \pm 237$ & $651 \pm 153$ & $710 \pm 139$ & $\mathrm{~A}-\mathrm{C}$ \\
Mean multiseriate ray height $(\mu \mathrm{m})$ & $1143 \pm 624$ & $1000 \pm 772$ & $3900 \pm 3566$ & $\mathrm{~A}-\mathrm{C}, \mathrm{B}-\mathrm{C}$ \\
Mean multiseriate ray width $(\mu \mathrm{m})$ & $62 \pm 27.7$ & $64 \pm 29.9$ & $86 \pm 40.3$ & $\mathrm{~A}-\mathrm{C}$ \\
\hline
\end{tabular}

\section{Discussion}

\section{Latitudinal trends}

This paper illustrates that latitude, which can be considered as a rough indicator of macroclimatic conditions, plays a considerable role in wood anatomical variation within the subfamily Vaccinioideae (Tab. 1-2). Our results generally agree with latitudinal trends established in previous studies on wood anatomy (e.g. BAAS 1973; VAN DER GRAAF \& BAAS, 1974; VAN Den Oever et al. 1981; Noshiro \& BaAs 2000). The length of tracheary elements (i.e., vessel elements, tracheids, fibre-tracheids and libriform fibres), tangential vessel diameter, and height of multiseriate rays are all negatively correlated with increasing latitude, while distinct growth rings, vessel density and the occurrence of helical thickenings throughout tracheary elements show a positive correlation (Figs. 1-7). The higher incidence of prismatic crystals in tropical Vaccinioideae compared to temperate members has been found in various plant groups, such as Rosaceae (ZHANG et al.
1992), Sapindaceae (KLAASSEN 1999), and other Ericaceae (Cox 1948; Greguss 1959; Lens et al. 2003), although it does not tend to be a general trend. Among these characters, presence (and location) of prismatic crystals and height of multiseriate rays provides clear phylogenetic signals within the subfamily (LENS et al. 2004, submitted). The distribution of prismatic crystals is mainly restricted to wood of the temperate Oxydendreae, some tropical Lyonia species (Lyonieae), and many tropical Vaccinieae. Furthermore, low multiseriate rays are observed in Oxydendreae, Lyonieae and Andromedeae s.s., relatively high rays are reported in Gaultherieae, and very high multiseriate rays are characteristic of most Vaccinieae (LENS et al. 2004, submitted). The conclusion published by BAAS (1982) that axial parenchyma is more abundantly present in tropical wood than in wood from temperate zones, is not supported in Vaccinioideae. Nearly all vaccinioids studied show scanty paratracheal parenchyma. Nevertheless, banded marginal parenchyma is restricted to a few tropical Vaccinieae members (LENS et al. submitted). 
Since the majority of tropical vaccinioid species grows at relatively high altitudes (above $1500 \mathrm{~m}$ ), it could be expected that latitudinal trends in the wood of the subfamily are rather obscure because of the macroclimatic similarities between tropical, montane environments and cold, temperate to boreal regions. However, the above-mentioned latitudinal correlations are surprisingly manifest at the subfamily level and within the genus Vaccinium, probably because of positive interactions with habit data (see below).

When studying wood anatomy from an ecological point of view, it is not surprising that several continuous wood anatomical characters are correlated with each other. Indeed, the highest $\mathrm{r}$-values, all significant at $0.5 \%$, occur between length of various types of tracheary elements; correlations of tracheary element length with vessel density and vessel diameter, and the correlation between vessel density and vessel diameter are also relatively high. Furthermore, height of multiseriate rays is significantly correlated with all these wood features.

Based on recent phylogenetic studies in Ericaceae, Vaccinioideae have a North American origin. Indeed, North American representatives are found in every major evolutionary line within the subfamily, and major taxa with a southern distribution area (e.g. Gaultheria and Vaccinieae) have been derived independently from northern temperate taxa via dispersal (KRON \& LUTEYN, in press, but see HEADs 2003). How long ago the first vaccinioids evolved is unclear, but they probably developed at the end of the Cretaceous, when a warmer climate prevailed and the latitudinal climatic gradient was gentle (Crowley \& NorTH 1991). Therefore, the wood structure of early vaccinioids was probably only slightly influenced by climatic differences. At the end of the Eocene, the climate became cooler and more seasonal (WoLfE 1994). This climatic change also influenced the wood structure, since fossil wood illustrates that the number of shorter vessel elements and distinct growth rings has increased since the Cretaceous, indicating a shift to a more seasonal climate (WHEELER \& BAAS 1991, 1993). In Vaccinioideae, this climatic change could have played an important role in the evolution of serveral northern taxa, for example, Andromeda (Andromedeae s.s.) and Chamaedaphne (Gaultherieae). Within Vaccinieae, the common ancestor of an Andean and Meso-American/Caribbean clade may have occurred across the Andean highlands and the mountains of Central America and the Antilles, suggesting that diversification within this clade occurred very late, namely during the last 20 million years when the Andes began to rise (KRON \& LUTEYN, in press). The homogeneous wood structure of the Andean and Meso-American/Caribbean clade could support this idea (LENS et al., submitted).

\section{Impact of frost}

Latitudinal trends can partly be explained by the impact of frost on wood structure. This is certainly the case for vaccinioids that grow in temperate to boreal regions of the northern and southern hemisphere, where frost occurs at least during one month per year. Since cold and freezing temperatures result in temporary inactivity of the cambium, this may explain why $86 \%$ of temperate to boreal species have distinct growth rings, while this feature occurs in only $44 \%$ of tropical species examined. Nearly all other vaccinioid specimens studied show indistinct growth rings (LENS et al., 2004, submitted). The relatively high percentage of tropical species with distinct growth rings is probably due to the large number of representatives growing at high elevations, although only a fraction of the species in this study grows above $3000 \mathrm{~m}$.

Another character that is clearly influenced by frost is vessel diameter. Mean vessel diameter of the 104 frost-free living species studied is significantly wider ( $39 \mu \mathrm{m} \pm 26$ ) compared to the 24 species that grow in areas with at least one month of frost per year $(20 \mu \mathrm{m}$ \pm 4 ). Likewise, nearly all frost susceptible species have a relative high vessel frequency (on average $300 \mathrm{~mm}^{-2}$ ). The functional significance of narrow vessel diameter and high vessel frequency can largely be explained in terms of increased safety of sap flow as a reaction to freeze-thaw cycles. The explanation for this is the greater likelihood of freezing-induced cavitation in wider vessels, in which a much larger amount of water is present. This trade-off between conduit diameter and susceptibility to cavitation has been demonstrated by ZimmermanN \& Brown (1971), SPERry \& Sullivan (1992), SPERry et al. (1994), and Davis et al. (1999). Moreover, the presence of narrow tracheids (and to a lesser extent fibre-tracheids with distinctly bordered pits) may also contribute to the safety of water transport in Ericaceae (WALlace 1986; CARLQUist 2001).

The impact of frost may also be illustrated by the type of vessel perforation plates. There is a tendency that species experiencing frost show (almost) exclusively scalariform perforations, which may negatively affect conductive efficiency and are suggested to catch air bubbles caused by freezing-induced cavitation (ZimMermanN 1983; Ellerby \& EnNos 1998; Schulte 1999). Tropical lowland species, on the other hand, exhibit usually simple vessel perforations (e.g. CARLquist 1975, 2001; BAAs et al. 1983; BAAs 1986). This trend is also apparent in Vaccinioideae: species growing in areas with at least one month of frost per year show a significantly higher frequency of scalariform perforations (on average $84 \% \pm 27$ ) than species living in frost-free areas (on average $62 \% \pm 39$ ), and also the mean number of bars is somewhat higher in species 
experiencing frost compared to frost-free species ( $12 \pm 6$ versus $9 \pm 7$ bars per perforation plate). Moreover, the percentage of species with exclusively scalariform vessel perforations is significantly higher in areas with frost than in frost free regions (respectively 54\% and $28 \%$ ). Nevertheless, some counter examples can be listed. For example, simple perforations are generally present in Vaccinium globulare $(100 \%)$ and V. uliginosum (85\%), two species that experience at least 30 days of frost per year. Exclusively scalariform perforation plates occur also in several frost-free species, belonging for instance to Agapetes, Agarista, Anthopterus, Ceratostema, Cavendishia, Demosthenesia, Gaultheria, Leucothoe, Lyonia, Pieris, Plutarchia, Sphyrospermum and Thibaudia.

\section{Altitudinal trends}

In general, altitudinal trends are much less obvious than latitudinal trends, which is in agreement with previous studies (VAN DER GRAaF \& BAAS 1974; VAN DEN Oever et al. 1981; BaAs 1986; Carlquist 2001). At the subfamily level, only vessel density shows a statistically significant correlation with increasing altitude, while clear altitudinal correlations are lacking within Vaccinium (Tab. 1-2). A possible explanation for the weak altitudinal correlations could be the major differences between day and night temperatures in tropical mountains. A separate analysis of the Andean species, which usually grow above $1500 \mathrm{~m}$, did not provide any higher correlations. This could also suggest that there might be a threshold altitude at $2000 \mathrm{~m}$, as suggested by Noshiro \& BAAs (2000), indicating that the influence of altitude above $2000 \mathrm{~m}$ is more or less similar for all woody taxa.

\section{Impact of habit and precipitation}

The relationship between quantitative wood anatomical features and influences of habit is in general agreement with previous analyses within woody angiosperms (BAas \& Schweingruber 1987; Carlquist 2001). Table 3 shows that shrubs are characterised by a high incidence of scalariform perforations, small vessel diameters, high vessel densities, short tracheary elements, and relatively narrow multiseriate rays. In lianas many wide vessel elements, a subsequently low vessel density, few scalariform perforation plates, and usually wide multiseriate rays occur. While shrubs and lianas show significant differences for these features, trees generally represent intermediate values. Nevertheless, the height of multiseriate rays demonstrates an aberrant correlation with habit types. We found that multiseriate rays are relatively low in trees, intermediate in shrubs, and high in lianas. A possible explanation for the low rays in trees could be due to the sampling and taxonomic impact: many tree species that were investigated belong to Oxydendreae and Lyonieae, two tribes that are characterised by low multiseriate rays (Lens et al., 2004). As documented by CARLQUIST (1989), wide vessels with simple perforation plates, broad rays, and an abundant presence of tracheids are common in lianas. CARLQUIST (1989) also mentioned that the length of tracheary elements in lianas does not differ greatly from that in woody, selfsupporting plants, which is in agreement with our data (Tab. 3). Generally, trends in growth form correspond with latitudinal trends, which is not so surprising because most of the specimens of the study group living in temperate to boreal regions are shrubs, most vaccinioid trees grow in the subtropics, and lianas are restricted to tropical habitats.

The impact of precipitation on the wood structure of Vaccinioideae is similar compared to the habit effect. Species from environments with 500 to $1000 \mathrm{~mm}$ annual precipitation show a high percentage of scalariform perforation plates, a narrow vessel diameter and high vessel density, short tracheary elements, and relatively narrow and low multiseriate rays, while species growing in very wet environments (more than $2500 \mathrm{~mm}$ annual precipitation) have a higher percentage of simple perforations, wider and fewer vessels, longer tracheary elements, and broader and higher multiseriate rays. Except for the percentage of scalariform perforation plates and vessel diameter, these features are all significant at the $0.5 \%$ level (Tab. 4). Vaccinioids occurring in habitats with an annual precipitation from 1000 to $2500 \mathrm{~mm}$ show intermediate values, although the height and width of multiseriate rays is similar to the values observed in species growing in areas with $1000-2500 \mathrm{~mm}$ annual precipitation. Because the amount of precipitation is one of the major features that is used to define major climatic regions, these trends are very similar to the latitudinal trends described above. Indeed, all species from very wet regions (> $2500 \mathrm{~mm}$ ) in this study are derived from the tropics, subtropical regions correspond well with areas with a annual precipitation of between 1000 and $2500 \mathrm{~mm}$, and in temperate to boreal areas and in savannah regions the amount of precipitation lies usually between 500 and $1000 \mathrm{~mm}$ per year.

\section{Conclusion}

Although most tropical Vaccinioideae grow at relatively high altitudes, this study demonstrates that latitude shows a clear impact on several wood anatomical characters within the subfamily and within Vaccinium. Since differences in growth forms agree rather well with macroclimatic regions, the impact of habit supports the 
latitudinal trends, and may explain the relatively high latitudinal correlation values. The effect of altitude on wood structure of Vaccinioideae and Vaccinium is negligible.

\section{Acknowledgements}

The directors of the National Botanic Garden of Belgium, the Royal Botanic Gardens of Edinburgh, and the curators of the wood collections of Kew, Leiden, Madison, Utrecht, and Tervuren are greatly acknowledged for their supply of wood samples. Special thanks go to Dr. G. D. Wallace (Rancho Santa Ana Botanic Garden) and Miss Fiona Inches (Royal Botanic Gardens, Edinburgh) for sending wood material. We thank Anja Vandeperre (K. U. Leuven) for technical assistance. This work has been financially supported by research grants of the K. U. Leuven (OT/01/25) and the Fund for Scientific Research - Flanders (Belgium) (F. W. O. - Vlaanderen) (G.104.01, 1.5.069.02, 1.5.061.03). Steven Jansen is a postdoctoral fellow of the Fund for Scientific Research - Flanders (Belgium) (F. W. O. - Vlaanderen).

\section{References}

BAAs, P. (1973): The wood anatomical range in Ilex (Aquifoliaceae) and its ecological and phylogenetic significance. - Blumea 21 : 193-258.

BAAS, P. (1982): Systematic, phylogenetic, and ecological wood anatomy - History and perspectives. In: BAAS, P. (ed.): New perspectives in wood anatomy. - Nijhoff/Junk Publishers, The Hague.

BAAs, P. (1986): Ecological patterns in xylem anatomy. In: Givnish, T. (ed.): On the economy of plant form and function. - Cambridge Univ. Pr., Cambridge.

BAAs, P. \& Schweingruber, F. (1987): Ecological trends in the wood anatomy of trees, shrubs and climbers from Europe. - IAWA Bull., new series 8: 245-274.

BAas, P.; Werker, E. \& FAhn, A. (1983): Some ecological trends in vessel characters. - IAWA Bull., new series 4: 141-159.

BaAs, P.; Esser, P. M.; VAn der Westen, M. E. T. \& Zandee, M. (1988): Wood anatomy of the Oleaceae. - IAWA Bull., new series 9: 103-182.

CARlquist, S. (1975): Ecological strategies of xylem evolution. - Univ. California Pr., Berkeley.

CARlQuist, S. (1989): Anatomy of vine and liana stems: a review and synthesis. In: Putz, F. E. \& Mooney, H. A. (eds.): The biology of vines. Cambridge Univ. Pr., Cambridge.

CARLQUIST, S. (2001): Comparative wood anatomy. Systematic, ecological, and evolutionary aspects of dicotyledon wood. 2nd ed. - Springer, Berlin.

Carlquist, S. \& Hoekman, D.A. (1985): Ecological wood anatomy of the southern Californian flora. - IAWA Bull., new series 6: $319-347$.

Cox, H. T. (1948): Studies in the comparative anatomy of the Ericales. I. Ericaceae-subfamily Rhododendroideae. Amer. Midl. Nat. 39: 220-245.
Crowley, T. J. \& North, G. R. (1991): Paleoclimatology. Oxford Univ. Pr., New York.

Davis, S. D.; Sperry, J. S. \& Hacke, U. G. (1999): The relationship between xylem conduit diameter and cavitation caused by freezing. - Am. J. Bot. 86: 1367-1372.

Dickison, W. C. (1989): Steps towards the natural system of the dicotyledons: vegetative anatomy. - Aliso 12: $555-566$.

Dickison, W. C. \& Phend, K. D. (1985): Wood anatomy of the Styracaceae: evolutionary and ecological considerations. - IAWA Bull., new series 6: 3-22.

Ellerby, D. J. \& EnNos, A. R. (1998): Resistances to fluid flow of model xylem vessels with simple and scalariform perforation plates. - J. Exp. Bot. 49 : 979-985.

Greguss, P. (1959): Holzanatomie der Europäischen Laubhölzer und Sträucher. Academia Kiado, Budapest.

HeADS, M. (2003): Ericaceae in Malesia: vicariance biogeography, terrane tectonics and ecology. - Telopea 10: $311-449$.

KLAassen, R. K. W. M. (1999): Wood anatomy of the Sapindaceae. - IAWA J., Supplement 2 : 1-214.

Kron, K. A. \& Luteyn, J. L. (In press): Origins and biogeographic patterns in Ericaceae: New insights from recent phylogenetic analyses. In: FrIIS, I. \& BALSEv, H. (eds.): Plant diversity and complexity patterns: Local, continental and global dimensions. - Biol. Skrift.

Kron, K. A. ; Judd, W. S. ; Stevens, P. F. ; Anderberg, A. A. ; CRAYN, D. M. ; GAdeK, P. A. ; Quinn, C. J. \& Luteyn, J. L. (2002): A phylogenetic classification of Ericaceae: molecular and morphological evidence. - Bot. Rev. 68: $335-423$.

Lens, F.; Gasson, P.; Smets, E. \& Jansen, S. (2003): Comparative wood anatomy of epacrids (Styphelioideae, Ericaceae s.1.). - Ann. Bot. 91: 835-857.

Lens, F.; Smets, E. \& Jansen, S. (2004): Comparative wood anatomy of Andromedeae s.s., Gaultherieae, Lyonieae and Oxydendreae (Vaccinioideae, Ericaceae s.1.). - Bot. J. Linnean Soc. 144: 161-179.

Lens, F.; Kron, K. A.; Luteyn, J. L. ; Smets, E. \& Jansen, S. (submitted): Comparative wood anatomy of the blueberry tribe (Vaccinieae, Ericaceae s.1.). - Ann. Missouri Bot. Gard.

LiU, J. \& Noshiro, S. (2003): Lack of latitudinal trends in wood anatomy of Dodonaea viscosa (Sapindaceae), a species with a worldwide distribution. - Am. J. Bot. 90: $532-539$.

LUTEYN, J. L. (2002): Diversity, adaptation, and endemism in Neotropical Ericaceae: biogeographical patterns in the Vaccinieae. - Bot. Rev. 68: 55-87.

Noshiro, S. \& BAas, P. (1998): Systematic wood anatomy of Cornaceae and allies. - IAWA J. 19: 43-97.

Noshiro, S. \& BAAs, P. (2000): Latitudinal trends in wood anatomy within species and genera: case study in Cornus s.l. (Cornaceae). - Am. J. Bot. 87: 1495-1506.

Noshiro, S. \& Suzuki, M. (1995): Ecological wood anatomy of Nepalese Rhododendron (Ericaceae). 2. Intraspecific variation. - J. Plant Res. 108: 217-233.

Noshiro, S \& Suzuki, M. (2001): Ontogenetic wood anatomy of tree and subtree species of Nepalese Rhododendron (Ericaceae) and characterization of shrub species. - Am. J. Bot. 88: 560-569. 
Noshiro, S.; Suzuki, M. \& OHвA, H. (1995): Ecological wood anatomy of Nepalese Rhododendron (Ericaceae). 1. Interspecific variation. - J. Plant Res. 108: 1-9.

Schulte, P. J. (1999): Water flow through a 20-pore perforation plate in vessels of Liquidambar styraciflua. - J. Exp. Bot. 50: 1179-1187.

Sperry, J. S. \& Sullivan, J. E. M. (1992): Xylem embolism in response to freeze-thaw cycles and water stress in ringporous, diffuse-porous, and conifer species. - Plant Physiol. 100: 605-613.

Sperry, J. S. ; Nicols, K. L. ; Sullivan, J. E. M. \& Eastlack, S. E. (1994): Xylem embolism in ring-porous, diffuseporous, and coniferous trees of northern Utah and interior Alaska. - Ecology 75: 1736-1752.

VAn den Oever, L.; BAAs, P. \& Zandee, M. (1981): Comparative wood anatomy of Symplocos and latitude and altitude of provenance. - IAWA Bull., new series 2: 3-24.

VAN DER GRAAF, N. A. \& BAAS, P. (1974): Wood anatomical variation in relation to latitude and altitude. - Blumea 22 : 101-121.

Wallace, G. D. (1986): Wood anatomy of Cassiope (Ericaceae). - Aliso 11: 393-415.

Wheeler, E. A. \& BaAs P. (1991): A survey of the fossil record for dicotyledonous wood and its significance for evolutionary and ecological wood anatomy. - IAWA Bull., new series 2: 3-24.

WheEler, E. A. \& BaAs P. (1993): The potentials and limitations of dicotyledonous wood for climatic reconstruction. - Paleobiology 19: 487-498.

Wolfe, J. A. (1994): Tertiary climatic changes at middle latitudes of western North America. - Palaeogeogr. Palaeoclimatol. Palaeoecol. 108: 95-105.

Zhang, S.; BaAs, P. \& ZandeE, M. (1992): Wood structure of the Rosaceae in relation to ecology, habit and phenology. - IAWA Bull., new ser. 13: 307-349.

ZimmermanN, M. H. (1983): Xylem structure and the ascent of sap. - Springer, Berlin-Heidelberg-New York.

ZimmermanN, M. H. \& Brown, C. L. (1971): Trees: structure and function. - Springer, Berlin-Heidelberg-New York.

\section{Appendix}

\section{Studied species, area of occurrence, collection identification number, specimen diameter}

Agapetes flava (Hook. F.) SLeumer: Bhutan (Chukka), A. Grierson \& D. Long 3076 (E 19822403), $10 \mathrm{~mm}$; A. hosseana Diels: Thailand (Chiang Mai), B. L. Burtt 958 (E 19672592), 7 mm; A. mannii HemsL.: Myanmar, F. Kingdon-Ward 19097 (E 19500046), 10 mm; A. sikkimensis AIRY SHAw: Bhutan (Phuntsholing), I. Sinclair \& D. Long 5778 (E 19842032), $12 \mathrm{~mm}$; A. variegata G. Don: India (Meghalaya), D. F. Chamberlain 106 (E 19751313), 9 mm; Agarista duckei (HuBER) JudD: Venezuela (Amazonas), B. Maguire etal. 42692 (Tw 36848), 58 mm; Agarista eucalyptoides (Cham. \& Schltdl.) G. Don: Brazil, G. G. Hatschbach \& J. C. Lindeman 20935 (Uw 20844), 70 mm; Agauria salicifolia Oliv.: Rwanda, G. Bouxin 877 (Tw 24171), mature;
Andromeda polifolia L.: Belgium (BR), F. Lens, $4.5 \mathrm{~mm}$; Anthopterus wardii BALL: Colombia (Nariño), J. L. Luteyn \& M. Lebrón-Luteyn 6865 (NY), 8 mm; Cavendishia bracteata (J. ST.-Hil.) Hoerold : Bolivia (La Paz), L. J. Dorr et al. 6890 (Lw), $12 \mathrm{~mm}$; C. compacta A. C. SM. : Colombia, van Rooden et al. 555 (Uw 25619), $15 \mathrm{~mm}$; C. callista Donn. SM.: Surinam (Lely Mountains), Lindeman \& Stoffers 502 (Uw 21835), $11 \mathrm{~mm}$; C. lindauiana Hoerold: Colombia, van Rooden et al. 630 (Uw 25642), $15 \mathrm{~mm}$; C. pubescens (Kunth) Hemsl.: Venezuela, L. Williams 10020 (Uw 35101), 43 mm; C. urophylla A. C. SM. : Colombia, van Rooden et al. 371 (Uw 25568), $21 \mathrm{~mm}$; Ceratostema reginaldii (Sleumer) A. C. SM.: Ecuador (Loja), L. J. Dorr \& I. Valdespino 6562 (Lw), 15 mm; Chamaedaphne calyculata MoEncH: Germany, E. Smets, Botanical Garden of Bochum (Germany), $5 \mathrm{~mm}$; Craibiodendron stellatum W. W. SM.: Thailand (Tunkamang), C. F. Van Beusekom \& R. Geesink 4361 (L), 57 mm; Demosthenesia spectabilis (Rusby) A. C. SM. : Peru (Cuzco), J. L. Luteyn 6452 (NY), $7 \mathrm{~mm}$; Dimorphanthera collinsii SLEUMER var. collinsii: Indonesia (Irian), Kalkman 4902 (Tw 23696), 60 mm; D. cornuta J. J. SM. var. cornuta: East New Guinea, Vink 17084 (Kw 11639, Uw 18298), 51 mm; D. dekockii J. J. SM. var. pubiflora SLEUMER: East New Guinea, Vink 17307 (Kw 11639, Uw 18316), 45 mm; D. kempteriana Schltr.: Indonesia (East Irian), Vink 16888 (Tw 23733), 44 mm; Diogenesia floribunda (A. C. SM.) Sleumer: Ecuador (NapoPastaza), J. L. Luteyn \& M. Lebrón-Luteyn 5675 (NY), 9 mm; D. tetrandra (A. C. SM.) Sleumer: Colombia (Cauca), J. L. Luteyn et al. 7388 (NY), $11 \mathrm{~mm}$; Diplycosia heterophylla Blume: Indonesia (Java, Gunong Pangrango), P. Woods 1046 (E 19680830), 9 mm; Disterigma alaternoides NIED.: Colombia (Cauca), J. L. Luteyn et al. 7400 (NY), $11 \mathrm{~mm}$; D. cryptocalyx A. C. SM.: Colombia (Huila), J. L. Luteyn \& M. Lebrón-Luteyn 7545 (NY), 7 mm; Gaultheria anastomosans (L.) H. B. K.: Colombia (Cauca), J. L. Luteyn, R. Callejas \& J. J. Pipoly 10085, 27 mm; Gaultheria buxifolia WILLD. var. buxifolia: Venezuela (Trujillo), J. L. Luteyn, M. LebrónLuteyn, L. Ruiz- Terán \& J. A. Dugarte 5195, 18 mm; Gaultheria buxifolia Willd. var. ellasantha (A. C. SM.) Luteyn: Colombia (Antioquia), J. L. Luteyn \& M. LebrónLuteyn 7079, 13 mm; Gaultheria buxifolia WILLD. var. secunda (J. Remy) Luteyn: Peru (Cuzco), J. L. Luteyn \& M. Lebrón-Luteyn 6376, 8 mm; Gaultheria erecta VENT.: Ecuador (Carchi), J. L. Luteyn \& M. Lebrón-Luteyn 5739, $8 \mathrm{~mm}$; Gaultheria erecta VENT.: Venezuela, Wagener (Kw 11654), $26 \mathrm{~mm}$; Gaultheria erecta Vent.: Venezuela (Tachira), J. L. Luteyn, M. Lebrón-Luteyn \& L. Ruiz- Terán 6020, 8 mm; Gaultheria eriophylla (PERsoon) Burtt. var. mucronata (J. Remy) Luteyn: Peru (Cuzco), J. L. Luteyn \& M. Lebrón-Luteyn 6375, 10 mm; Gaultheria reticulata $\mathrm{H}$. B. K. : Ecuador (Azuay), J. L. Luteyn \& E. Cotton 11158, 18 mm; Gaultheria rigida H. B. K.: Colombia, A. M. Cleef 2799 (Uw 20769), 9 mm; Gaultheria shallon PURsh: Belgium (BR), F. Lens, $6.5 \mathrm{~mm}$; Gaultheria strigosa BENTH. var. strigosa: Colombia (Antioquia), J. L. Luteyn \& M. LebrónLuteyn 7101, $10 \mathrm{~mm}$; Gaultheria strigosa BENTH. var. strigosa: Ecuador (Azuay), J. L. Luteyn \& M. Lebrón-Luteyn 5777, 12 mm; Gaultheria tomentosa H. B. K.: Peru (Amazonas, Chachapoyas), J. L. Luteyn \& M. Lebrón-Luteyn 5569, 13 mm; Gaylussacia baccata C. KосH: Belgium, F. Lens (BR), $7 \mathrm{~mm}$; G. decipiens Снам. var. decipiens: Brazil, 
P. Clausen 1840, $6 \mathrm{~mm}$; Leucothoe axillaris D. DoN: USA (Georgia), collector unknown (E 19881623), 13 mm; Leucothoe grayana MАХІM.: origin and collector unknown (E 19080096), 13 mm; Lyonia ferruginea NuTT.: USA (Florida), A. Curtis (Tw 53206), mature; Lyonia heptamera URB.: Dominican Republic, J. Pimentel \& M. Mejia 993 (MADw 49103), 31 mm; Lyonia jamaicensis D. Don: Jamaica, World Colombian Exposition 14997 (MADw 3549), mature; Lyonia lucida C. Koch: USA, C. D. Mell (MADw 2951), 22 mm; Lyonia ovalifolia (WALL.) DRUDE: Japan (Kumamoto), For. Exp. Stat. 2244 (Tw 17276), mature; Lyonia squamulosa M. Martens \& Galeotti: Mexico, D. Breedlove 9683 (MADw 23903), $23 \mathrm{~mm}$; M. crassa A. C. SM.: Colombia (Cauca), J. L. Luteyn et al. 7378 (NY), $20 \mathrm{~mm}$; M. ericae Sleumer: Ecuador (Pichincha), J. L. Luteyn \& M. LebrónLuteyn 5639 (NY), 15 mm; M. hirtiflora (BENTH.) A. C. SM. : Colombia (Cauca), J. L. Luteyn et al. 7386 (NY), 13 mm; Macleania loeseneriana Hoerold: Ecuador (Carchi), J. L. Luteyn \& M. Lebrón-Luteyn 5726 (NY), 18 mm; M. pentaptera Hoerold: Colombia (Valle), J. L. Luteyn \& M. Lebrón-Luteyn 6957 (NY), 19 mm; M. rupestris (Kunth) A. C. Sm.: Venezuela, L. Williams 10904 (Uw 35316), 18 mm; Notopora cardonae A. C. SM.: Venezuela (Bolívar), J. L. Luteyn 9596 (NY), 10 mm; N. schomburgkii Ноок. F.: Venezuela, Maas et al. 5808 (Uw 27397), 10 mm; Orthaea fimbriata LUTEYN : Ecuador (Morona-Santiago), J. L. Luteyn \& M. Lebrón-Luteyn 5794 (NY), 15 mm; Oxydendrum arboreum (L.) DC.: USA (Ohio), A. W. Green 245 (Tw 19787), mature; Pernettya mucronata (L. F.) A. SPRENG. : The Netherlands, A. M. W. Mennega (UN 835), $13 \mathrm{~mm}$; Pernettya mucronata (L. F.) A. Spreng. var. angustifolia (LindL.) ReICHE: Argentina (Rio Negro), P. Dezarbo 433 (BR), 8 mm; Pernettya rigida DC.: Chili (Juan Fernández Islands), Meyer 9490 (Uw 14995), 66 mm; Pieris formosa D. Don: India (Meghalaya), Birla Institute of Scientific Research (Tw 45532), mature; Pieris japonica (ThunB.) G. Don: Belgium (BR), F. Lens, 8 mm; Plutarchia rigida (Benth.) A. C. SM. : Colombia (Cauca), J. L. Luteyn 10108 (NY), 5 mm; Polyclita turbinata (Kuntze) A. C. SM.: Bolivia (Cochabamba), J. L. Luteyn 15453 (NY), $10 \mathrm{~mm}$; Psammisia sp.: Colombia, van Rooden et al. 359 (Uw 25565), $30 \mathrm{~mm}$; P. ferruginea A. C. Sm.: Ecuador, Maas et al. 3041 (Uw 23589), 20 mm; P. graebneriana HoERold: Colombia (Nariño), J. L. Luteyn \& M. Lebrón-Luteyn 6809 (NY), $10 \mathrm{~mm}$; P. guianensis Klotzsch: Venezuela (Amazonas), B. Maguire et al. 42397 (Tw 36530), $11 \mathrm{~mm}$; P. cf. ulbrichiana HoErold: Ecuador (Pichincha), J. L. Luteyn \& M. Lebrón-Luteyn 6532 (NY), $12 \mathrm{~mm}$; Satyria sp.; Colombia (Antioquia), J. L. Luteyn et al. 7017 (NY), 16 mm; S. sp.: Brazil, B. Maguire et al. 48650 (Uw 16976), $35 \mathrm{~mm}$; S. sp.: Brazil, B. Maguire et al. 46784 (Uw 17005), $22 \mathrm{~mm}$; S. sp.: Colombia (Antioquia), J. L. Luteyn \& M. Lebrón-Luteyn 7177 (NY), 15 mm; S. carnosiflora LANJ.: Venezuela (Amazonas). B. Maguire et al. 42061 (Tw 36580), 15 mm; S. meiantha Donn. SM.: Mexico, D. Breedlove 9746 (MADw 23933), mature; S. panurensis (Meisn.) NiED.: Brazil, B. Maguire et al. 48650 (MADw 20301), mature; Siphonandra elliptica KLotzsch: Peru (Cuzco), J. L. Luteyn \& M. Lebrón-Luteyn 6377 (NY), 14 mm; Sphyrospermum sp.: Ecuador (Pichincha), G. Argent (E 19762390), $11 \mathrm{~mm}$; S. buxifolium PoEPP. \& ENDL.: Ecuador, G. Argent (E 19762390), 6 mm; Symphysia race- mosa (VAhl) Stearn: Dominica, Chambers 2555 (Uw 15385), $22 \mathrm{~mm}$; T. pendula Kцотsch: Venezuela (La Mucuy), Breteler 3476 (Uw 11013), 35 mm; T. vegasana A. C. SM. : Colombia (Boyacá), J. L. Luteyn et al. 7590 (NY), $13 \mathrm{~mm}$; Thibaudia angustifolia Hoок.: Peru (Amazonas), J. L. Luteyn \& M. Lebrón-Luteyn 5528 (NY), 13 mm; T. floribunda H. B. K. : Ecuador (Carchi), J. L. Luteyn \& M. LebrónLuteyn 5725, $14 \mathrm{~mm}$; T. formosa (KLOtzsch) Hoerold: Venezuela (Amazonas), B. Maguire et al. 27673 (Tw 36552), $20 \mathrm{~mm}$; T. jahnii S. F. BlAKe: Venezuela (Mérida), J. L. Luteyn et al. 6185 (NY), $15 \mathrm{~mm}$; T. martiniana A. C. SM. : Ecuador (Pichincha), J. L. Luteyn \& M. Lebrón-Luteyn 5654 (NY), $24 \mathrm{~mm}$; T. pachypoda A. C. SM.: Colombia, Cuatrecasas 19876 (Uw 25099), $11 \mathrm{~mm}$; T. parvifolia HoEROLD: Colombia (Cauca), J. L. Luteyn \& M. Lebrón-Luteyn 6897 (NY), $14 \mathrm{~mm}$; T. rigidiflora A. C. Sм.: Colombia (Valle), J. L. Luteyn \& M. Lebrón-Luteyn 6985 (NY), 23 mm; Vaccinium sp.: USA (Hawaii), W. Stern 2980 (Tw 24148), 33 mm; $V$. angustifolium BENTH.: Belgium, F. Lens (BR), $6 \mathrm{~mm}$; $V$. arboreum MARSCHAL: USA (Texas), H. Nogle 258 (Tw 18270), mature; V. atrococcum A.Heller: USA (Maryland), collector unknown (Kw 11706), mature; V. bancanum MiQ.: Brunei, collector unknown, (Kw 74737), $67 \mathrm{~mm}$; V. barandanum VIDAL var. barandanum: Philippines, M. Jacobs 7249 (Uw 33743), $45 \mathrm{~mm}$; V. berberidifolium (A. Gray) Sкоттsв.: USA (Hawaii), Stern \& Herbst 496 (Uw 18579), $9 \mathrm{~mm}$; V. bracteatum ThunB.: China (Guangdong), Forest Research Institute 1623 (Tw 42071), mature; V. calycinum SM.: USA (Hawaii), W. Stern 2950 (Tw 24121), $17 \mathrm{~mm}$; V. consanguineum Klotzsch : Costa Rica (San José), M. Wiemann 13 (Uw 30897), mature; V. corymbodendron Dun. : Colombia, J. Cuatrecasas 20784 (Tw 20784), mature; V. corymbosum L.: Canada (Quebeq), R. Dechamps 5003 (Tw 33895), $8 \mathrm{~mm}$; V. cumingianum VIDAL: Philippines, M. Jacobs 7270 (Uw 33746), 36 mm; V. exaristatum KURZ: India (Assam, Lushai Hills), N. E. Parry 45 (Kw 11747), $36 \mathrm{~mm}$; V. exul Bolus: South Africa, J. Prior 464, $23 \mathrm{~mm}$; V. floccosum (L. O. Williams) Wilbur \& Luteyn: Panama (Chiriquí), Maas et al. 4957 (Uw 26277), $33 \mathrm{~mm}$; V. floribundum H. B. K. : Bolivia (Cumba de Sama), J. R. De Sloover 399 (BR), 5 mm; V. globulare RYDB.: USA (Washington), R. Dechamps 4460 (Tw 46335), $15 \mathrm{~mm}$; V. leschenaultii WIGHT : India, collector unknown (Kw 70598), mature; V. leucanthum SchltdL.: Mexico (Puebla), L. Lebacq 73 (Tw 24590), adult; V. maderense LiNK: Spain (Madeira), N. H. Mason (Kw 11745), mature; V. membranaceum Ноок.: USA (Oregon), R. Dechamps 4325 (Tw 46029), 9 mm; V. meridionale Sw. : Venezuela, L. Williams 10896 (Uw 35314), mature; V. myrtillus L.: Belgium (Luik), R. Dechamps (Tw 43142), $8 \mathrm{~mm}$; V. occidentale A. GRAY: USA (Oregon), R. Dechamps 4414 (Tw 46260), mature; V. ovatum PURSH: USA (Oregon), $R$. Dechamps 4418 (Tw 46267), $23 \mathrm{~mm}$; V. parvifolium SM.: USA (Oregon), R. Dechamps 4310 (Tw 45996), $27 \mathrm{~mm}$; V. puberulum C. F. W. MEISSN. var. subcrenulatum MAGUIRE, Steyerm. \& Luteyn: Guyana, Maas et al. 5733 (Uw 27342), $13 \mathrm{~mm}$; V. scoparium LEIBERG: USA (Oregon), R. Dechamps 4383 (Tw 46187), 6 mm; V. stanleyi SchweINF.: Democratic Republic of Congo (Kivu), P. Deuse 55 (BR), 9 mm; V. uliginosum L: Norway (Hordaland), R. Dechamps 6033 (Tw 38581), $6 \mathrm{~mm}$; Zenobia pulverulenta POLLARD: eastern USA, collector unknown (E 19721932), 10 mm. 